КУРЮКИН Андрей Николаевич - кандидат политических наук, старший научный сотрудник Центра комплексных социальных исследований Института социологии Федерального научно-исследовательского социологического центра РАН (117218, Россия, г. Москва, ул. Кржижановского, 24/35, кopn.5; kuriukin@mail.ru)

\title{
COVID-19 КАК ВЫЗОВ ПОЛИТИЧЕСКОЙ СИСТЕМЕ И ДЕМОКРАТИИ В РОССИИ И В МИРЕ
}

\begin{abstract}
Аннотация. Сегодня в условиях COVID-19 каждое государство избирает свой способ реакции на этот глобальный вызов. Не во всех обществах эта реакция оказывается идентичной. Где-то, как, например, в Италии и Испании, запаздывают, а где-то, как в США и Иране, пускают все на самотек, а в КНР и Российской Федерации принимают серьезные меры социально-политического воздействия. В таких условиях основная задача настоящей статьи заключается в том, чтобы выявить характерные для современных политических систем и демократий реакции на вызов COVID-19 и спрогнозировать перспективы их развития в обозримом будущем.
\end{abstract}

Ключевые слова: политика, политическая система, вызов, коронавирус, демократия

П андемия COVID-19 разворачивается в то время, когда политическая система, свойственная последней четверти XX - первым десятилетиям XXI в., узловым компонентом которой выступает демократия, находится в упадке. Согласно данным, собранным Freedom House, демократия находится в рецессии более 10 лет, и все больше граждан в разных странах, включая и признанных лидеров демократии, каждый год теряют, а не получают гражданские и политические права [Repucci 2020: 4].

Ключевой проблемой является то, что COVID-19 может превратить демократическую рецессию в депрессию, что грозит поворотом политических систем к авторитаризму, скорость распространения чего по всему миру может быть сравнима с современной пандемией. Как отмечает С. Шмемман (New York Times), «Китай и некоторые из его союзников указывают на успех Пекина в борьбе с пандемией коронавируса в качестве веского основания для авторитаризации

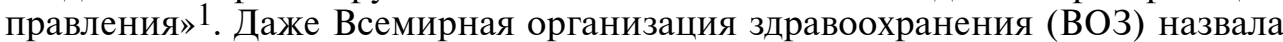
систему насильственных запретов, введенных в КНР, «возможно, самым амбициозным, своевременным и результативным политическим средством сдерживания болезней в истории». Возникает вопрос: является ли Китай исключением, или автократические режимы в целом смогли принять более жесткие политические меры, чтобы сдержать распространение вируса? И если так, были ли они более эффективными? Данная статья написана в рамках выполнения государственного задания по теме НИР на 2019-2021 гг. «Российское общество перед новыми вызовами: динамика социально-экономического положения, ценностных ориентаций и социального участия различных групп населения».

Чтобы исследовать поставленные выше вопросы, целесообразно рассмотреть институциональные и культурные основы ответных мер правительств на пандемию COVID-19. Используем для этого систему, предложенную авторским коллективом, руководимым К. Фрей, в мае 2020 г. [Frey, Chen, Presidente 2020]. Их методология предполагает измерение строгости политики ограничительных мер национальных правительств, введенных для борьбы с пандемией в разных странах, для чего использовался оксфордский трекер отслеживания реакции правительств на коронавирус $(O x C G R T)$, предоставляющий информа-

${ }^{1}$ Schmemann S. 2020. The Virus Comes for Democracy. - New York Times. April 2. 
цию о ключевых политических мерах сдерживания эпидемии, включая закрытие школ и рабочих мест, ограничение на поездки, запрет на публичные собрания и требование самоизоляции. Для оценки эффективности этих мер сдерживания распространения вируса ими было предложено использовать отчеты по COVID-19 от Google.

Полученные результаты показывают, что более эффективной выступила мера принудительного ограничения трансграничной мобильности, которая позволила исключить или снизить доставку вируса в не пораженные или незначительно пораженные регионы и в большей степени воспрепятствовать формированию так называемых трансграничных или, более того, континентального масштаба очагов вируса. Такие меры, как самоизоляция, перевод национальной образовательной системы в онлайн-режим и прочие меры имели непосредственное отношение к сдерживанию эпидемии на национальном уровне. Генеральными политическими мерами по сдерживанию распространения $C O V I D-19$ объективно стали именно ограничительные меры, прежде всего в отношении либеральных прав и свобод гражданина, где на передний план вышло ограничение свободы передвижений, собраний и т.п., которые составляют основу демократии как таковой в современном ее понимании.

Отсюда на передний план выходит вопрос - станет ли авторитарный поворот закономерной тенденцией дальнейшего, постпандемического развития политических систем в государствах мира? Примеры движения в этом направлении уже существуют. Так, на Филиппинах президент Родриго Дутерте захватил еще большую власть и пригрозил введением режима военного положения в виде месячной блокировки страны. А 30 марта 2020 г. венгерский парламент принял закон о коронавирусе, который наделяет правительство Виктора Орбана беспрецедентными чрезвычайными полномочиями на неопределенный период времени.

Однако судя по тому, как существующие автократические режимы отреагировали на кризис, не следует ожидать ни ускорения демократической рецессии, ни близкого авторитарного разворота. Для этого утверждения есть несколько оснований. Во-первых, это отсутствие прозрачности в автократических режимах, что стало крупнейшим негативным фактором в борьбе с пандемией. Ярчайшим примером здесь является Китай, где замалчивание проблемы вспышки коронавируса не смогла исправить даже последующая успешная общенациональная мобилизация: после того как председатель Си Цзиньпин дал «зеленый свет», распространению информации о происходящем и введению жестких ограничительных мер, первоначальное отсутствие прозрачности задержало решительные меры по обузданию вируса до его распространения в Китае и по всему миру. В свою очередь, в Туркменистане пошли еще дальше - граждан арестовывали исключительно за то, что они публично обсуждали вспышку болезни, и врачам запрещено ставить диагноз COVID-19. Во-вторых, исследования автора показывают, что, хотя в авторитарных политических системах вводят декларативно более жесткие ограничения, демократические политические системы более эффективны в практической реализации политических мер ограничительного характера как в отношении трансграничной мобильности, так и в отношении самоизоляции. В то время как автократии часто стремятся извлечь выгоду из предполагаемых угроз, маловероятно, что их политический modus operandi в борьбе с пандемией или другими вызовами в этих условиях распространится в остальном мире.

Рассматривая политические реакции ключевых акторов мировой политической арены на COVID-19 как вызов, следует начать с анализа поведения политических систем ключевых игроков региона - источника пандемии - Юго- 
Восточной Азии. Это, закономерно, Китай (КНР), Южная Корея и Тайвань. Характеризуя реакцию китайской политической системы на COVID-19 как вызов, следует констатировать, что КНР, по справедливому утверждению Ф. Фукуямы, это не только авторитарный режим, но и страна с сильной государственностью [Fukuyama 2014]. Как подчеркивает Т. Тальхельм, Китай, страны и регионы, входящие в его ойкумену, и указанные Южная Корея и Тайвань относятся к обществам с высоким уровнем коллективистской культуры, несмотря на то, что в последних авторитарный режим отсутствует [Talhelm et al. 2014]. Как показывает прикладной анализ автора, успех политической борьбы с COVID-19 следует увязывать со многими имманентными факторами, применительно к которым соблюдение ограничений трансграничной мобильности и внутренних социальных ограничений как основных способов предотвращения распространения COVID-19 является результатом, а не исходным положением.

Коллективистские общества более успешны в борьбе со вспышкой вируса. Результаты исследований автора говорят о том, что коллективистская культура, обеспечивающая конформность, групповую лояльность и послушание старшему в иерархии облегчает коллективные действия [Gorodnichenko, Roland 2017]. Таким образом, странах Восточной Азии, которые в высшей степени коллективистски настроены (по шкале Хофстеда), привычка носить маску для защиты сограждан и оставаться дома по указанию руководства заметно контрастирует с отношением граждан Запада [Hofstede 2001].

Запад - это достаточно широкое понятие, объединяющее весьма различные страны, народы и социально-политические общности. Двумя крупнейшими представителями так называемой западной цивилизации являются сегодня Евросоюз и США. Наиболее глубокой социокультурной парадигмой этих обществ и объединений является приверженность специфическим ценностным комплексам как основа их общественно-политического единства. Для США таким комплексом является представление об «американском образе жизни»; в свою очередь, для Евросоюза - либеральные гражданско-правовые и политические ценности, выступающие основой так называемой политики европейской идентичности.

Последняя на примере подключения широких масс к борьбе с распространением COVID-19 путем соблюдения социальных ограничений окончилась полным провалом. Граждане либо не соблюдали режим ограничений (самоограничений) вообще, либо регулярно его грубо нарушали. Можно констатировать, что существует социально-политический разрыв между, прежде всего, руководством Евросоюза, его национальными правительствами и широкими массами населения, консенсус между которыми оставляет желать много лучшего. Весьма положительным оказался опыт Великобритании, где профсоюзы своими силами обеспечивали соблюдение ограничительных мер. Срыв политики идентичности произошел в рамках Евросоюза и на более высоком - межнациональном - уровне. Тот факт, что каждая страна делает свое собственное здравоохранение приоритетной задачей, разрушает политическую и экономическую целостность и солидарность, которые являются наиболее важным двигателем ЕС. Обобщая, отметим, что ЕС, который был сформирован политикой всеуровневой идентичности, начинает разрушаться изнутри, обращаясь к новому изоляционизму.

Для США вспышка COVID-19 - первое серьезное испытание со времен вьетнамской войны. Реагируя на него, США предпочли закрыть свои границы с союзниками по НАТО, как случае драматических призывов Италии о помощи. «Новая реальность» американской политики, которую президент Дональд 
Трамп провозгласил в своей инаугурационной речи в 2016 г., проявила себя весной 2020 г. наиболее полно. Уже сегодня внутри США отмечается огромная некомпетентность национальной администрации, пустившей на начальном этапе все на самотек, руководствуясь советами «экспертов», характеризовавших такое положение дел как «выработку иммунитета в национальных масштабах». Американские граждане оплатили эти «советы» более чем 100 тыс. летальных исходов среди заболевших к концу мая 2020 г.

Отдельный вопрос - реакция внешнеполитической составляющей американской политической системы на вызов COVID-19. Она реализуется в двух ключевых направлениях - это взаимоотношения с союзниками и конкуренция с КНР. По первому направлению мы приводили выше пример Италии, которая вместе с еще целым рядом стран - активных участников НАТО задались вопросом, насколько продуктивен дорогостоящий альянс с США, которые, несмотря на свои передовые технологии, оказались неспособными обеспечить себя и своих союзников?

Относительно взаимоотношений с КНР сегодня объективно наблюдается новое усиление глобальной конкуренции. Опыт вспышки коронавируса показывает, что в новую эпоху конкуренция между великими державами станет жестокой и не будет предполагать исключений, как, например, сотрудничество США и СССР в отношении выработки единой политики по борьбе против оспы во времена «холодной войны». Ничем не ограниченное соперничество КНР и США, которые, как представлялось ранее, будут осуществлять сотрудничество с сознанием глобальной ответственности во время кризиса, наносит ущерб всему миру.

На Ближнем Востоке наиболее показательным выступает пример Ирана как действительно религиозно-авторитарного государства. Реакция иранского религиозно-политического руководства на вспышку эпидемии COVID-19 в общем-то была предсказуемой. Будучи уверенными в своей наибольшей близости к Всевышнему, который оградит свой народ от этой напасти, руководство страны обратилось к тактике замалчивания и не стало вводить ограничения, связанные с отменой коллективных молений в мечетях и, что более важно, празднования праздника Новруз, которые выступают важнейшими факторами обеспечения национально-религиозной идентичности в Иране. К сдерживанию информации о распространении $C O V I D-19$, которую в официозе называли слухами, был привлечен и КСИР, осуществлявший аресты «распространителей слухов» и запрет выхода всех газет, которые распространяли информацию о развитии эпидемии ${ }^{1}$. Все это привело к катастрофе: число инфицированных коронавирусом в Иране к концу апреля, по оценкам оперативного штаба (Хамид Соури), достигло 500 тыс. чел. ${ }^{2}$

Обращаясь к реакции России на вызовы, связанные с COVID-19, необходимо отметить, что она протекала у нас на глазах. На момент написания этой статьи (май 2020 г.), мы все еще придерживаемся ограничительных мер, установленных в конце марта 2020 г. В таких условиях, возможно, они и не дали своего положительного эффекта полностью, но объективно Российской Федерации пока удается избегать развития событий по американскому сценарию, где число выявленных случаев COVID-19 стремится к 2 млн случаев.

Российские власти, начиная с президента России Владимира Путина, ока-

${ }^{1}$ Iran bans printing of all newspapers, citing spread of coronavirus. March 31, 2020. URL: https:// cpi.org/2020/03/iran-bans-printing-of-all-newspapers-citing-spread/ (accessed 08.10.2020).

2 «Была паника и истерия». Что происходит в Иране, где число заразившихся коронавирусом рискует превысить 500 тысяч человек. Доступ: https://lenta.ru/ articles/2020/04/13/in_iran/ (проверено 08.10.2020). 
зались готовыми к кризисной ситуации и, проявив необходимую инициативность и прозрачность, надлежащим образом информировали массы о происходящем и принимали соответствующие меры. Большую роль здесь сыграли ключевые характеристики современного российского общества, где вместе и наравне сосуществуют общая уверенность в способности властей держать ситуацию под контролем, в нормальной работе государственных институтов и в то же время доверие рыночным институтам, способным обеспечить удовлетворение потребностей россиян ${ }^{1}$. Наиболее адекватную и эффективную реакцию на вызовы $C O V I D-19$ продемонстрировали сегодня миру коллективистские общества, существующие в условиях авторитарного политического режима или тяготеющие к нему. Вместе с успешностью коллективных действий им исторически присущ более медленный экономический рост, меньший динамизм в решении встающих социальных проблем и инновационность, чего настоятельно требуют такие вызовы, как COVID-19 [Gorodnichenko, Roland 2011]. Борьба с COVID-19 потребует координации мер по противодействию распространению вируса, а также инноваций, чтобы найти метод лечения и вакцины. Здесь авторитаризм будет скорее тормозящим агентом из-за склонности авторитарных властей к волюнтаристским решениям. Пандемии являются глобальными по определению, и, следовательно, необходим глобальный ответ, который потребует совмещения инновационного научного потенциала отдельных стран с координационными и производственными возможностями других, а не простого разворота в сторону авторитаризма...

\section{Список литературы}

Frey C.B., Chen C., Presidente G. 2020. Democracy, Culture, and Contagion: Political Regimes and Countries Responsiveness to Covid-19. URL: https://www.oxfordmartin.ox.ac.uk/downloads/academic/Democracy-Culture-and-Contagion_May13. pdf (accessed 08.10.2020).

Fukuyama F. 2014. Political Order and Political Decay: From the Industrial Revolution to the Present Day. Farrar, Straus and Giroux Publishing. $672 \mathrm{c}$.

Gorodnichenko Y., Roland G. 2011. Which Dimensions of Culture Matter for Long-Run Growth? - American Economic Review. Vol. 101. Is. 3. P. 492-98.

Gorodnichenko Y., Roland G. 2017. Culture, Institutions, and the Wealth of Nations. - Review of Economics and Statistics. Vol. 99. Is. 3. P. 402-416.

Hofstede G. 2001. Culture's Consequences: Comparing Values, Behaviors, Institutions and Organizations across Nations. London: Sage Publications. 577 p.

Repucci S. 2020. A Leaderless Struggle for Democracy. Freedom in the World 2020. Washington, DC: Freedom House. 33 p.

Talhelm T., Zhang X., Oishi S., Shimin C., Duan D., Lan X., Kitayama S. 2014. Large-scale Psychological Differences within China Explained by Rice Versus Wheat Agriculture. - Science. Vol. 344. Is. 6184. P. 603-608.

1 Проверка на прочность для власти: что россияне думают о пандемии коронавируса. Доступ: https://www.levada.ru/2020/03/19/proverka-na-prochnost-dlya-vlasti-chto-rossiyanedumayut-o-pandemii-koronavirusa/ (проверено 19.05.2020). 
KURIUKIN Andrei Nikolaevich, Cand.Sci. (Pol.Sci.), Senior Researcher of the Center for Complex Sociological Researches, Sociological Institute - branch of the Federal Center of Theoretical and Applied Sociology, Russian Academy of Sciences (bld. 5, 24/35 Krzhizhanovskogo St, Moscow, Russia, 117218; kuriukin@mail.ru)

\title{
COVID-19 AS A CHALLENGE TO POLITICAL SYSTEM AND DEMOCRACY IN RUSSIA AND IN THE WORLD
}

\begin{abstract}
The COVID-19 pandemic is unfolding at a time when the political system inherent in the last quarter of the $20^{\text {th }}$ - the first decades of the $21^{\text {st }}$ century, with democracy as the key component, is in decline. According to data compiled by Freedom House, democracy has been in a recession for more than a decade, and more and more citizens in different countries, including recognized leaders of democracy, lose and not get civil and political rights every year. The key problem is that COVID-19 could turn a democratic recession into a depression, which threatens to turn political systems toward authoritarianism, the spread of which around the world can be compared to a modern pandemic. The question arises if autocratic regimes generally are able to take tougher political measures to curb the spread of the virus. If so, are they more effective or China is an exception?

This article is written as part of the state task on the topic of the NIR for 2019-2021 «Russian Society before New Challenges: Dynamics of Social and Economic Situation, Value Orientations and Social Participation of Various Population Groups".

Keywords: policy, political system, challenge, coronavirus, democracy
\end{abstract}

